\title{
High seroprevalence of Toxoplasma gondii antibodies in wild boars hunted in the Game Breeding Center in north-eastern Poland')
}

\author{
AGNIESZKA WISZNIEWSKA-ŁASZCZYCH, BEATA WYSOK, JOANNA WOJTACKA, \\ JOANNA SZTEYN, MIROS ŁAW M. MICHALSKI*, MARTA SOŁTYSIUK
}

\begin{abstract}
Department of Veterinary Public Health Protection, Faculty of Veterinary Medicine, University of Warmia and Mazury in Olsztyn, ul. Oczapowskiego 14, 10-917 Olsztyn *Department of Parasitology and Invasive Diseases, Faculty of Veterinary Medicine, University of Warmia and Mazury in Olsztyn, ul. Oczapowskiego 13, 10-917 Olsztyn
\end{abstract}

\section{Wiszniewska-Łaszczych A., Wysok B., Wojtacka J., Szteyn J., Michalski M., Sołtysiuk M. High seroprevalence of Toxoplasma gondii antibodies in wild boars hunted in the Game Breeding Center in north-eastern Poland \\ Summary}

Toxoplasmosis is a cosmopolitan zoonotic disease caused by Toxoplasma gondii, an intracellular protozoan. The main source of infection for humans is meat contaminated with tissue cysts, the main invasive form of the parasite. The muscle tissue of seropositive animals of the family Suidae, subfamily Sus (domestic pig, wild boar) are the most common sources of infections with Toxoplasma gondii. The aim of this study was to determine the prevalence of T. gondii infections in the meat of wild boars (Sus scrofa) based on measurements of T. gondii antibodies in the enzyme-linked immunosorbent assay (ELISA). One hundred samples of muscle tissue were obtained from wild boars hunted in the Game Breeding Center in north-eastern Poland. The animals were divided into three age groups: weaners (27), subadults (38) and adults (35). The prevalence of toxoplasmosis was very high in the analyzed population, and $71 \%$ of the animals were classified as seropositive in ELISA. Antibodies against $T$. gondii were detected in $62.9 \%$ of weaners, $73.6 \%$ of subadults and $74.2 \%$ of adult boars. The seroprevalence of $T$. gondii antibodies was significantly higher in the animals hunted in the Game Breeding Center in comparison with the national average determined by other authors. Such extensive spread of the parasite in the natural environment can be attributed to geographic location, landform, presence of waterbodies, local climate, the size of the wild boar population and the spread of castor bean ticks (Ixodes ricinus).

Keywords: Toxoplasma gondii, wild boar, ELISA, meat

Toxoplasma gondii is a widespread protozoan and an intercellular parasite in humans and warm-blooded animals. The parasite has three infectious stages: tachyzoites, tissue cysts and oocytes which are shed in the environment. Animals of the family Felidae, mainly domestic cats, are definitive hosts for T. gondii. Millions of oocysts reach the environment with cat feces. Oocysts are resistant to physical and chemical factors in the natural environment, including acids, bases and many disinfectants. They are capable of surviving for up to 28 days at a temperature of $21^{\circ} \mathrm{C}$, and they can spread across considerable distances with ground water (2). Wild boars feed on carrion, and they act as intermediate hosts for the parasite.

The research was financed by KNOW (Leading National Research Centre) Scientific Consortium „Healthy Animal-Safe Food”, by the decision of Ministry of Science and Higher Education No. 05-1/KNOW2/2015.
Toxoplasmosis is one of the most prevalent parasitic diseases affecting humans in nearly all regions of the world. According to estimates, around one-third of the global population are infected with the parasite (15), and seroprevalence ranges from $10 \%$ to even $90 \%$ $(7,13)$. In Europe, the prevalence of toxoplasmosis exceeds $60 \%$ in the Netherlands, Austria, Germany and Italy. In Poland, it is estimated at 50-60\% (24). In humans, toxoplasmosis is generally asymptomatic, and in rare cases it may produce non-specific symptoms such as swollen lymph nodes, fever, muscle pain, rash and general fatigue, which disappear after several weeks. In patients with compromised immune systems the disease can develop into an acute infection, and it may lead to encephalitis, meningitis, pneumonia, myocarditis and myositis. Toxoplasmosis is particularly dangerous for pregnant women, posing a significant 
risk of fetal damage. Trophozoites are released from tissue cysts into the mother's bloodstream; they can cross the placenta and cause mental retardation and ocular damage in the fetus. Infections with $T$. gondii can also lead to miscarriage and premature birth (27). Raw or undercooked meat containing tissue cysts and water contaminated with oocysts are the main sources of infection for humans. Poor hygiene during the processing and storage of raw meat increase the risk of infection $(8,25)$.

According to estimates, the consumption of contaminated meat is responsible for $50 \%$ of toxoplasmosis cases in humans (27). In 2007, the European Food Safety Authority recommended that EU Member States implement systems for monitoring the prevalence of T. gondii infections in livestock and free-range animals, including wild boars, intended for human consumption (10). Poland is a large producer of wild boar meat, and a total of 341,000 animals were hunted in the $2015 / 2016$ season. Up to $80 \%$ of domestic output is exported, mainly to Germany, France, Belgium, the Netherlands, Italy and Switzerland (http://stat.gov.pl/ obszary-tematyczne/rolnictwo-lesnictwo/lesnictwo).

The objective of this study was to determine the prevalence of Toxoplasma gondii in the meat of Eurasian wild boars hunted in the Game Breeding Center in north-eastern Poland within the designated hunting district. Pursuant to the provisions of the Hunting Law of 13 October 1995, game breeding centers have been established to restore the populations of endangered wild animals, breed game animals for hunting grounds in other parts of the country, and set guidelines for successful wildlife management (17).

\section{Material and methods}

Sampling. One hundred samples of diaphragm muscles weighing around $50 \mathrm{~g}$ each were collected from the carcasses of wild boars that had been hunted in the Game Breeding Center in north-eastern Poland in November 2015 and January 2016. The samples were collected in the hunting ground, labeled, placed in secure containers and transported to the laboratory of the Department of Veterinary Public Health Protection at the Faculty of Veterinary Medicine of the University of Warmia and Mazury in Olsztyn. The samples were divided into three groups based on the animals' age. The first group of 27 samples was obtained from weaners (aged up to 12 months, body weight of $15-30 \mathrm{~kg}$ ); the second group of 38 samples was collected from subadults (aged 12-24 months, body weight of up to $60 \mathrm{~kg}$ ); and the third group of 35 samples was obtained with adult boars (body weight above $60 \mathrm{~kg}$ ).

Sample preparation for analysis. In the laboratory, the samples were frozen at a temperature of $-20^{\circ} \mathrm{C}$ and stored for 60 (samples collected in January 2016) to 120 days (samples collected in November 2015). Frozen samples were placed in sterile centrifuge tubes, thawed at room tem- perature for 12 hours and centrifuged at $6000 \mathrm{rpm}$ for 10 minutes to obtain meat juice.

Serological analysis. Meat juice was analyzed with the ID Screen Toxoplasmosis Indirect Multi-species ELISA kit (IDvet, France) for the detection of $T$. gondii antibodies in the serum, plasma and meat juice of various animal species. According to the manufacturer's instructions, $50 \mu 1$ of samples of meat juice were placed in plate wells, diluted with $50 \mu 1$ of the enclosed buffer solution, and incubated at room temperature for 45 minutes. The plates were rinsed three times with the enclosed rinsing solution added at around $300 \mu \mathrm{l}$ per well. A conjugate solution was added at $100 \mu \mathrm{l}$ per well, and the plates were incubated at room temperature for 30 minutes. The plates were rinsed three times, the substrate solution was added at $100 \mu \mathrm{l}$ per well, and the plates were incubated for 15 minutes in darkness. The Stop Solution was added at $100 \mu 1$ per well when the desired staining intensity was reached. Two samples with positive control serum and 2 samples with negative control serum were also prepared. The plates were read with the Biogenet UVM 340 microplate reader at $450 \mathrm{~nm}$ wavelength. The sample-to-positive $(\mathrm{S} / \mathrm{P}$ ) ratio (sample $\mathrm{OD} /$ positive control OD $\times 100$ ) was calculated for each sample. Samples with $\mathrm{S} / \mathrm{P} \geq 50 \%$ were classified as positive.

Statistical analysis. The results were analyzed statistically in Statistica PL 12 software (StatSoft Polska) with the use of the chi-square test. The null hypothesis (there are no significant differences in the prevalence of $T$. gondii infections between age groups) was rejected when $\mathrm{p} \leq 0.05$.

\section{Results and discussion}

The presence of Toxoplasma gondii antibodies was detected in meat juice from 71 out of the 100 tested samples, including 17 samples from weaners (62.9\%), 28 samples from subadults (73.6\%) and 26 samples from adult wild boars (74.2\%) (Fig. 1). The differences in the prevalence of toxoplasmosis between weaners and subadults $(\mathrm{t}=1.160526, \mathrm{p}=0.2502)$, and between weaners and adults $(\mathrm{t}=1.142369, \mathrm{p}=0.257915)$ were not statistically significant. The null hypothesis was not rejected.

Serological tests characterized by high sensitivity and specificity are the most popular method for

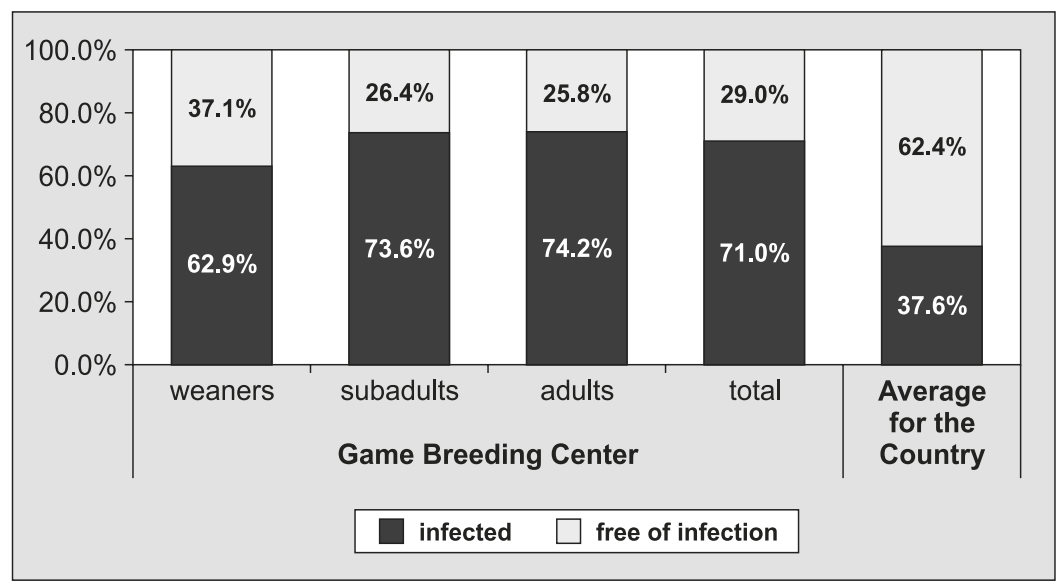

Fig. 1. Prevalence of Toxoplasma gondii infections in wild boars from different age groups based on antibody levels in muscle tissue 
diagnosing T. gondii infections in animals based on the presence of specific antibodies. Serological tests produce reliable results in domestic pigs (Sus scrofa domestica) because seropositivity in this animal species is closely linked with the presence of tissue cysts in the carcass (18). In our study, serological tests were carried out on the assumption that they would produce equally reliable results in wild boars (Sus scrofa) which are also members of the family Suidae, subfamily Sus. The seroprevalence of $T$. gondii antibodies was very high $(71 \%)$ in wild boars hunted in north-eastern Poland, and it significantly exceeded the values reported by other authors. In a study by Witkowski et al. (29), the average seroprevalence of $T$. gondii antibodies was determined at $37.6 \%$ based on analyses of tissue samples from wild boars hunted in 12 Polish regions. Similar results were reported in other European countries: seroprevalence was determined at $33 \%$ in Latvia (5), 33\% in Finland (14) and 36-38\% in Spain (11, $21)$. Lower seroprevalence rates were observed in the Netherlands at 24\% (16), Germany at 21\% (26) and Austria at 19\% (9). Toxoplasma gondii antibodies were detected in less than $10 \%$ of the examined animals in Slovakia and Switzerland $(1,4)$. Seroprevalence rates higher than 50\% were reported only in two European countries: France and Sweden $(20,28)$. In the Czech Republic, the average seroprevalence was determined at $40 \%$, and the prevalence of toxoplasmosis ranged from $32 \%$ to $59 \%$ in wild boars from different regions (19). In Poland, toxoplasmosis was also diagnosed in hares, roe deer, red foxes, badgers, red deer and small rodents which play an important role in the transmission of $T$. gondii in the natural environment (24).

It is generally believed that wild boars become infected by foraging in the environment contaminated with $T$. gondii oocysts and feeding on infected rodents and birds (intermediate hosts), tissues of livestock and game animals, and carrion containing tissue cysts (22). Invasive forms of $T$. gondii thrive in regions with high humidity and relatively low ambient temperature. The region investigated in this study is characterized by higher annual precipitation and lower ambient temperature than the national average (http://www.kzgw.gov.pl/ files/file/Materialy i Informacje/Programy/Program wodno Srodowiskowy/Zalacznik 3 Projekt PWS. pdf.). These conditions contribute to the survival of invasive forms of the parasite, and they probably explain the high number of infected wild boars in the evaluated region. North-eastern Poland is also one of the least populated Polish regions. Population density in the area of the Game Breeding Center is only 27 inhabitants per $\mathrm{km}^{2}$, whereas the national average is 123 inhabitants per $\mathrm{km}^{2}$ (http://olsztyn.stat.gov.pl/ statystyczne-vademecum-samorzadowca). These data stand in contrast with the results of published studies where population density was found to be directly correlated with the prevalence of toxoplasmosis in wild boars. According to Richomme (20), Bartoszek (3) and
Racka (19), the number of infected animals increases with a rise in population density. The above has been attributed to a higher number of domestic cats and rodents as well as greater availability of waste animal tissue (28).

The high prevalence of toxoplasmosis in the investigated region can be attributed to the size of the wild boar population. Since the beginning of the $21^{\text {st }}$ century, wild boar populations have been growing steadily in most European countries. In Poland, the estimated number of wild boars soared from 118,000 in 2000, to more than 284,600 in 2014, and 249,600 on 31 March 2016. The present population density is estimated at 0.94 animals per $\mathrm{km}^{2}$. The Region of Warmia and Mazury (where the Game Breading Center is located) is characterized by one of the highest population densities of wild boars in the country, which reached 11.65 animals per $\mathrm{km}^{2}$ in 2016 (http://stat.gov.pl/obszarytematyczne/rolnictwo-lesnictwo/lesnictwo). According to Sroka (23), the increase in tick populations (Ixodes ricinus) can play a role in the infection of $T$. gondii in wild boars. The risk of tick infections is also highest in north-eastern Poland.

In this study, the prevalence of toxoplasmosis was compared in differently aged wild boars. The disease was more prevalent in subadults and adults than in weaners, but the observed differences were not statistically significant. The analyzed animals were infected per os while foraging in the environment contaminated with invasive forms of $T$. gondii (12). Significant differences in the seroprevalence of $T$. gondii antibodies were reported in the Czech Republic (19) and Spain (21), but not in South Carolina (USA) (6), Slovakia (1) or Corsica (20).

The popularity of wild boar meat is on the rise due to its availability, moderate price and changes in consumers' preferences and eating habits. However, meat contaminated with parasitic cysts cannot be differentiated from uninfected meat during veterinarysanitary inspections. The consumption of meat from seropositive animals and the failure to observe basic hygiene precautions during evisceration and skinning of carcasses and processing of meat contribute to the risk of $T$. gondii infections in humans (24).

Wild boars are exposed to T. gondii parasites in the natural environment. In boars hunted in north-eastern Poland, seroprevalence rates significantly exceeded the Polish and European average. Our findings indicate that invasive forms of $T$. gondii are widely distributed in natural habitats, thus increasing the risk of infection in wild boars in the evaluated region. High seroprevalence of $T$. gondii antibodies cannot be ruled out in other species of wild animals in this region. Such extensive spread of the parasite in the natural environment can be attributed to geographic location, landform, presence of water bodies and the local climate. Due to the principles underlying their activity, Game Breeding Centers can also contribute to the spread of toxoplasmosis to 
other Polish regions. Hunting tourism and export of wild boar meat contaminated with tissue cysts can increase the prevalence of disease among consumers not only in Poland but also in other European regions and countries.

\section{References}

1. Antolova D., Reiterova K., Dubinsky P.: Seroprevalence of Toxoplasma gondii in wild boars (Sus scrofa) in the Slovak Republic. Ann. Agric. Environ. Med. 2007, 14, 71-73.

2. Barragan A., Sibley L. D.: Transepithelial migration of Toxoplasma gondii is linked to parasite motility and virulence. J. Exp. Med. 2002, 195, 1625-1633.

3. Bartoszek K., Orłowska B., Anusz K.: Elementy bioasekuracji łańcucha żywnościowego zapobiegające zarażeniom zwierząt i ludzi Toxoplasma gondii. Życie Wet. 2011, 86, 714-716.

4.Berger-Schoch A. E., Bernet D., Doherr M. G., Gottstain B., Frey C. F.: Toxoplasma gondii in Switzerland. A serosurvey based on meat juice analysis of slaughter pigs, wild boar, sheep and cattle. Zoonoses Public Hlth. 2011, 58 , 472-478

5. Deksne G., Kirjusina M.: Seroprevalence of Toxoplasma gondii in domestic pigs (Sus scrofa domestica) and wild boars (sus scrofa) in Latvia. J. Parasitol. 2013, 99, 44-47.

6. Diderrich V., New J. C., Noblet G. P., Patton S.: Serologic survey of Toxoplasma gondii antibodies in free-ranging wild hogs (Sus scrofa) from the Great Smoky Mountains National Park and from sites in South Carolina. J. Eukaryot. Microbiol. 1996, 43, 122S

7. Dubey J. P.: Toxoplasmosis of Animals and Humans, $2^{\text {nd }}$ edn Boca Raton, Florid: CRC Press. 2010, 64 pp.

8. Dubey J. P., Thayer D. W.: Killing of different strains of Toxoplasma gondii tissue cyst by irradiation under defined condition. J. Parasitol. 1994, 80, 764-767.

9. Edelhofer R., Prosl H., Kutzer E.: Trichinellosis and Toxoplasmosis in wild pigs of eastern Austria. Wien. Tierartzl. Monatsschr. 1966, 83, 225-229.

10. EFSA: Surveillance and monitoring of Toxoplasma in humans, food and animals, scientific opinion of the panel on biological hazards. EFSA Journal 2007, 583, 1-64.

11. Gauss C. B., Dubey J. P., Vidal D., Ruiz F., Vincente J., Marco I., Lavin S., Gortazar C., Almeria S.: Seroprevalence of Toxoplasma gondii in wild pigs (Sus scrofa) from Spain. Vet. Parasitol. 2005, 131, 151-156.

12. Halos L., Thebault A., Aubert D., Thomas M., Perret C., Geers R., Alliot A. Escotte-Binet S., Ajzenberg D., Darde M. L., Durand B., Boireau P., Villena I. An innovative survey underlining the significant level of contamination by Toxoplasma gondii of ovine meatconsumed in France. Int. J. Parasitol. 2009, 40, 193-200

13. Jimenez-Coello M., Acosta-Viana K. Y., Guzmán-Marín E., Puerto-Solís M. Ortega-Pacheco A.: Toxoplasmosis: A relevant zoonotic food borne disease in tropical conditions. African Journal of Microbiology Research 2012, 6 , 2956-2964.
14.Jokelainen P., Nareaho A., Halli O., Heinonen M., Sukura A.: Farmed wild boars exposed to Toxoplasma gondii and Trichinella spp. Vet. Parasitol. 2012, 187, 323-327.

15. Munoz M., Liesenfeld O., Heimesaat M. M.: Immunology of Toxoplasma gondii. Immunological Reviews 2011, 240, 269-285.

16. Opsteegh M., Swart A., Fonville M., Dekkers L., van der Giessen J.: Age related Toxoplasma gondii seroprevalence in Duch wild boar inconsistent with lifelong persistence of antibodies. PLoS One 2011, 6, e16240.

17. Pałubicki J., Grajewski J., Zambrzycki R., Różycki B.: Cele, zasady oraz podstawowe problemy funkcjonowania ośrodków hodowli zwierzyny Lasów Państwowych na przykładzie ośrodka hodowli zwierzyny Lutówko i ośrodka hodowli zwierzyny Runowo. Zarządzanie Ochroną Przyrody w Lasach 2013, 7, 347-359.

18. Puchalska M., Orłowska B., Anusz K.: Wieprzowina - główne źródło zarażeń Toxoplasma gondii u ludzi. Życie Wet. 2014, 89, 600-604

19. Racka K., Bartova E., Budikova M., Vodrazka P.: Survey of Toxoplasma gondi antibodies in meat juice of wild boar (Sus scrofa) in several districts of the Czech Republic. Ann. Agric. Environ. Med. 2015, 22, 231-235.

20. Richomme C., Alfonso E., Tolon V., Ducrot C., Halos L., Alliot A., Perret C., Thomas M., Boireau P., Gilot-Fromont E.: Seroprevalence and factors assiociated with Toxoplasma gondii infection in wild boar (Sus scrofa) in Mediterranean island. Epidemiol. Infect. 2010, 138, 1257-1266.

21. Ruiz-Fons F., Vincente J., Vidl D., Hofle U., Villanua D., Gauss C., Segales J. Almeria S., Montoro V., Gortazar C.: Seroprevalence of six reprodictiv pathogens in European wild boar (Sus scrofa) from Spain: the effect on wild boar female reproductive performance. Theriogenology 2006, 65, 731-743.

22. Solaymani-Mohammadi S., Petri W. A. Jr: Zoonotic implication of the swinetransmitted protozoa infections. Vet. Parasitol. 2006, 140, 189-203.

23. Sroka J., Chmielewska-Badora J., Dutkiewicz J.: Ixodes ricinus as a potential vector of Toxoplasma gondii. Ann. Agric. Environ. Med. 2003, 10, 121-123.

24. Sroka J., Ziomko I., Cencek T., Karamon J.: Toksoplazmoza - pasożytnicza zoonoza. Życie Wet. 2008, 83, 568-571

25. Sroka J., Zwoliński J., Dutkiewicz J.: Seroprevalence of Toxoplasma gondi in farm and wild animals from the area of Lublin province. Bull. Vet. Inst. Pulawy 2007, 51, 535-540.

26. Tackmann K.: Seroprevalence of antibodies against Toxoplasma gondii in wild boars (Sus scrofa), [in:] Shirley M (ed.): EUR 18476- COST 820 Vaccines against animal coccidiosis - Annual report. Luxembourg, Office for Official Publications of the European Communities 1997, 167 pp.

27. Tenter A. M., Heckeroth A. R., Weiss L. M.: Toxoplasma gondii: from animals to humans. Int. J. Parsitol. 2000, 30, 1217-1258

28. Wallander C., Frossling J., Vagsholm I., Uggala A., Lunden A.: Toxoplasma gondii seroprevalence in wild boars (Sus scrofa) in Sweden and evaluation of ELISA test performance. Epidemiology \& Infection 2015, 143, 1913-1921.

29. Witkowski L., Czopowicz M., Nagy D. A., Potarniche A. V., Aoanei M. A., Imonov N., Mickiewicz M., Welz M., Szaluś-Jordanow O., Kaba J.: Seroprevalence of Toxoplasma gondii in wild boars, red deer and roe deer in Poland. Parasite 2015, 22, 17-20.

Adres autora: Agnieszka Wiszniewska-Laszczych, DVM, PhD, Oczapowskiego 14, 10-917 Olsztyn, Poland; e-mail: aga@uwm.edu.pl 